\title{
Zygmunt Gałecki
}

Akademia Humanistyczno-Pedagogiczna im. Tarasa Szewczenki w Krzemieńcu

\section{Polski gwarowy przysłówek przyboś, na przyboś i nazwisko Przyboś}

Przedmiotem badania i wyjaśnienia etymologicznego w artykule jest nazwisko Przyboś skojarzone z gwarowym przysłówkiem przyboś, na przyboś 'częściowo, nieco boso'. To nazwisko nosił wybitny poeta pochodzenia chłopskiego, Julian Przyboś (1901-1970), urodzony w Gwoźnicy na Podkarpaciu. Po studiach polonistycznych na Uniwersytecie Jagiellońskim był nauczycielem gimnazjalnym w Sokalu, Chrzanowie i Cieszynie. Był także współtwórcą i głównym przedstawicielem grupy literackiej Awangarda Krakowska, której awangardowe idee w liryce realizował najpełniej, programowo odcinając się „od metafizyki i kultu przeszłości na rzecz konstruktywnych działań cywilizacyjnych” (hasło: „miasto - masa - maszyna”), zrywając „z opisowością, sentymentalizmem i retoryką pojęciową na rzecz skrótu artystycznego, ekonomizmu środków, odległych znaczeń metaforycznych" [Lam 1984: 36-37]. W liryce Przybosia obecnych jest wiele własnych elementów związanych z kulturą ludową i tradycją romantyczną ${ }^{1}$. Można go również zaliczyć do nurtu poezji lingwistycznej (,poeta to słowiarz”).

Wydawało się, że nazwiska Przyboś nie objaśnił Kazimierz Rymut w słowniku etymologicznym nazwisk polskich $[\mathrm{NP}]^{2}$. Nie ma tego nazwiska w artykule pod hasłem Przyboś, bo nie ma w słowniku takiego hasła i choćby

1 Język artystyczny grupy literackiej zbadał Janusz Sławiński [1965]. Immanentną analizę twórczości skoncentrowaną na dziele przedstawił Jerzy Kwiatkowski [1972]. Związki z romantyczną tradycją literacką w poetyce Przybosia analizowała Danuta Zamącińska [1970, 1971]. Z prac językoznawczych zob. Maria Zembaty-Michalakowa 1982.

2 Współczesnego nazwiska Przyboś i wariantów Przybos, Przybosz nie uwzględnił też Bogusław Kreja w opisie w książce Słowotwórstwo polskich nazwisk. Struktury sufiksalne [Kreja 2001]. 
odsyłacza do odpowiedniego artykułu; nie ma go też pod hasłem Bosy 1388 (data pierwszego poświadczenia), gdzie - w słowniku o układzie gniazdowym - powinno się było znaleźć [NP, t. 1: 49], tak jak znajduje się Bos-ak 1337 i bosak 'człowiek chodzący boso'. Nazwiska Przyboś nie omówił też Stanisław Rospond w rozdziale drugim książki Mówią nazwy [Rospond 1976]³, zatytułowanym $O$ nazwach osobowych - zarówno w całym tekście, jak i pod punktem Skad pochodza poniższe imiona i nazwiska? Kalendarz etymologiczny wybranych imion i nazwisk oraz pod punktem Charakterystyczne nazwiska od imion chrzestnych [Rospond 1976: 161-181, 181-182]. Dokładne poszukiwania w słowniku Kazimierza Rymuta doprowadziły jednak do wyniku: nazwiska Przyb-os, Przyb-osz 1400, Przyb-oś znajdują się w artykule pod hasłem „Przyb 1189 - od im[ion] złożonych typu Przybysław, Przybywoj, też od przybyć [...]" [NP, t. 2: 311-312], gdzie zostały objaśnione w sposób dwuznaczny jako pochodzące albo od imion złożonych, albo od czasownika przybyć. Wyłonił się nowy problem. Którą z podanych hipotez da się naukowo uzasadnić, a którą trzeba odrzucić?

Tak jak nazwisko Przyboś, tak i przysłówek przyboś, na przyboś nie znalazł miejsca w słownikach etymologicznych języka polskiego i w pierwszym polskim słowniku rozumowanym Samuela Bogumiła Lindego [1807-1814, 1854-1860]. Nie ma go nawet oczytany i znający bodaj wszystkie źródła staro- i średniopolskie Aleksander Brückner [1927]. U Lindego w artykule pod hasłem bosy nie ma podhasła przybosy 'trochę bosy, półbosy', ale jest przecież boskiem 'bosym sposobem, boso' z cytatem z Fabiana Birkowskiego, są bosiny w $1 \mathrm{~m}$. 'chodzenie boso', zestawione z ros. бocoma ${ }^{4}$ i z cytatem z Adama Naruszewicza, są wreszcie bosak 'człowiek bosy, boso chodzący' i boso 'bez obuwia', poparte cytatem z Grzegorza Piramowicza: Dzieci niech się ucza bez obuwia wszelkiego boso chodzić [Linde 1994-1995, t. 1: 149-150, Powinności nauczyciela, b.r.]. Z gwar wieluńskich XX wieku boski 'biedny, goły' od bosy we frazemie boski jak oficer podała Honorata Skoczylas-Stawska, informując, że wyraz występuje w południowej Wielkopolsce i w Świętokrzyskiem [Skoczylas-Stawska 1976] $]^{5}$. Jedynie w Stowniku gwar polskich Jana Karłowicza

3 Ta książka mądrze popularyzuje onomastykę, badania i metody badań onomastycznych w Polsce na tle słowiańskim i europejskim. Warto ją przypomnieć, gdy coraz częściej pojawiają się ,nowe-stare” pomysły popularyzowania wiedzy z tego zakresu i gdy językoznawcy nie nadążają z krytyką tych pomysłów [zob. np. Koper 2008; Duda, Koper 2009; Walczak 2013].

4 Por. босота, босина r.ż., босоножие r.n. 'nagość nóg, stan bez obuwia' [Dal 1881: 119].

5 SGP PAN, t. 2: 401 podaje boski w znaczeniu 'biedny, pożałowania godny' (Jędrysek, pow. lubliniecki; Więciórka, pow. myślenicki; Dzierżysławice, pow. prudnicki), ale frazemu boski 
znajdujemy kilka przykładów użycia wyrazu przyboś ‘obuty bez pończoch', 'na gołą nogę (kładzenie obuwia)', 'bez pończoch, a w trzewikach’ z gwar wielkopolskich, małopolskich, mazowieckich i podlaskich, np. Ona w zimie przyboś chodzi (z okolic Drohiczyna) [Karłowicz 1900-1911, t. 1: 407]. Te same informacje ujęte bardziej syntetycznie podaje Stownik warszawski [Karłowicz, Kryński, Niedźwiedzki 1900-1927, t. 5: 263]. Oba słowniki nie poświadczają wyrażenia przyimkowego na przyboś.

Czyżby zatem wyrazu znanego z gwar polskich nie było w staropolszczyźnie? Okazuje się, że brak przysłówka przyboś w słownikach nie jest przeoczeniem ich autorów. Nie znaleźli go w dawnych źródłach pisanych. W monografii gramatycznej przymiotników z przedrostkiem przy- Henryka Perzowa napisała: „W polszczyźnie okresu średniopolskiego występowały interesujące nieodmienne formy typu przydtuż i przydłuższym. Mogły one pełnić funkcję przymiotników i przysłówków" [Perzowa 1969: 5]. Nie znała takich wyrazów staropolszczyzna. Najwcześniejsze zapisy znalazła autorka pracy w poradniku lekarskim O ziołach i o mocy jich, tzw. Zielniku Stefana Falimirza z roku 1534, potem $\mathrm{u}$ innych autorów XVI wieku, np. przybłękitny i przybłękitniejszym u Jana Mączyńskiego, przysłońszy subsalsus u Mączyńskiego, przysłońszym, nasłoniał nieco u Grzegorza Knapiusza (1621), przywyż w słowniku Knapiusza, przystarz w słowniku Lindego. W XVII wieku - podaje Perzowa - formacje nieodmienne były już w regresie [Perzowa 1969] ${ }^{6}$. Formacji przyboś nie znalazłem w pracy Perzowej, mimo że uznaje ona ten przysłówek za przykład reprezentatywny typu PRZYDŁUŻ w swoim materiale. Dodałbym jeszcze do tej charakterystyki, co się okaże istotne w toku analizy, że formy nieodmienne były zawsze zakończone spółgłoską fonetycznie lub funkcjonalnie miękką, jak wskazują przykłady przyleń 'przyleniwszy', przyłyś 'łysawy', przyśleṕ 'ślepawy' [Linde 1994-1995, t. 4: 684, bez cyt., nie oznacza miękkości $p$ ], przydtuz 'przydługi', przystarz 'przystary', przysłódz 'słodkawy' itd. Ta spółgłoska występuje w funkcji formantu słowotwórczego? ${ }^{7}$.

O przysłówku przyboś w znaczeniu 'nosić obuwie na bosych nogach, bez skarpet, pończoch czy onuc', czyli ‘częściowo, nieco boso’ (reprezentującym typ przydtuż) czytamy w pracy Perzowej: „Przysłówek ten jest zupełnie

jak oficer nie zawiera. Por. też przysłówek boski || bosko 'z nagimi stopami, boso' i przymiotnik bosny 'o nodze: w obuwiu bez pończoch lub skarpet': Pšyboś to jest po polsku: obuu bosno noge (Paprotki, pow. giżycki).

6 Kilka przykładów wymienił Jan Łoś [1925: 131].

7 Oczywiście z opisowego, nie historycznego punktu widzenia, jak np. w Poznań - bo nie można powiedzieć, że jest to nazwa niemotywowana, gdy pierwotnie formantem było *-j6. W tej sprawie zob. Doroszewski 1963: 273. 
zleksykalizowany - świadczy o tym różnorodność jego postaci fonetycznych i możliwość występowania w połączeniu z przyimkami” [Perzowa 1969: 115]. Różnorodne postaci fonetyczne - pokazane na mapach i w indeksie wyrazów [MAGP, t. 8, mapa 365. Przyboś, oprac. Irena Winkler-Leszczyńska; t. 13: Indeksy i źródła, s. 75] - to: przyboś i na przyboś, przybóś i na przybóś, w przyboś, przybość, na przybość, na przybóć, przyboszć, na przybórz, w przybóś, przybóść i na przybóść. Jak widać, zróżnicowanie postaci fonetycznych dotyczy wygłosu wyrazu (rozpodobnienie wygłosowej spółgłoski, adideacja do obuć, inne) i oboczności samogłoski rdzennej $o: o ́$. Nie omawiamy ich dokładniej, bo nie dotyczą bezpośrednio tematu artykułu. Co do zasięgu geograficznego formacji przyboś Perzowa, interpretując mapę 365 MAGP, zauważyła, że nie ma ona zasięgu ogólnopolskiego; izoleksa

omija dwa regiony, z których pochodzili szesnastowieczni autorzy używający form typu przydluż, Krakowskie (Oczko) i Łęczycko-Sieradzkie (Mączyński). Jednocześnie jednak jej niemal ogólnopolski zasięg zdaje się potwierdzać pogląd, że formy krótkie miały w wieku XVI charakter ogólnopolski. Brak formacji przyboś w okolicach Krakowa i w Sieradzko-Łęczyckiem można wytłumaczyć jej późniejszym zanikiem na tych terenach. [Perzowa 1969: 115]

Przechodzimy do uzasadnienia hipotezy etymologicznej, która zakłada, że podstawą apelatywną nazwiska Przyboś był tożsamy z nim przysłówek przyboś, na przyboś (chodzić), w przyboś (chodzić) itp. W wypadku gdy wyraz podstawowy ma zasięg ogólnogwarowy, związanie z nim nazwiska odapelatywnego za pomocą danych geograficznych i statystycznych, wydaje się, nie ma znaczenia. Przezwisko, następnie nazwisko mogło powstać w każdym miejscu i w różnym czasie. Konieczne jest oparcie się na materiale filologicznym, biorąc jednak pod uwagę rozmieszczenie geograficzne nazwiska. W 1990 roku nazwisko Przyboś miało w Polsce 187 nosicieli. Matecznikiem tego nazwiska jest niewątpliwie Podkarpacie; tak można interpretować dane ze Słownika nazwisk wspótcześnie w Polsce używanych, wydanym przez Rymuta:

a) woj. rzeszowskie 53, przemyskie 22, krośnieńskie 27, nowosądeckie 5, dalej krakowskie 10, katowickie 2, odpryski północne: tarnobrzeskie 5, lubelskie 3, siedleckie 4; w sumie: $131=70 \%$,

b) z migracji zachodniej: woj. opolskie 8 , legnickie 13, wrocławskie 14, wałbrzyskie 4, i północno-zachodniej: Warszawa 9, woj. gdańskie 7, szczecińskie 1; w sumie: $56=30 \%$.

W słowniku odnajdujemy jeszcze wariantywne postaci Przybosz 2 (woj. ostrołęckie 1, wałbrzyskie 1) i Przybos 0 (z frekwencją zerową, czyli nazwiska 
osób w 1990 roku już nieżyjących lub o których w banku danych PESEL nie było dokładniejszych informacji).

Jeżeli Przybosz i Przybos były (są) rzeczywistymi wariantami tej samej nazwy osobowej Przyboś (wariant $a$ ), to jako późniejsze nazwiska powinny mieć takie samo lub podobne rozmieszczenie geograficzne. Warianty $b$ (Przybosz) i c (Przybos) nie mogłyby powstać w zupełnym oddaleniu od wariantu podstawowego $a$, czyli nie mając $\mathrm{w}$ nim oparcia. Wszystko wskazuje na to, że Przybosz i Przybos są formacjami jednostkowymi, ,wykolejonymi” i bez geografii (niezwiązanymi z podkarpackim Przyboś) albo też nobliwymi przekształceniami pospolitego Przyboś, łatwo kojarzonego z apelatywnym przyboś. Uzasadnieniem wariantywności form nazwisk Przyboś \| Przybosz \| Przybos są analogiczne nazwiska zakończone spółgłoską szeregu $s, s z$, ś, np.: Przytas 7 (woj. katowickie 6, zielonogórskie 1), Przylas 3 (woj. katowickie 2, opolskie 1) || Przyłaś 1 (woj. katowickie); Przybysz 13382 (Warszawa 2307, woj. siedleckie 1024, lubelskie 262 itd.) || Przybyś 648 (woj. radomskie 136, lubelskie 102, tarnobrzeskie 61, katowickie 49, tarnowskie 25 itd.).

Dla porządku dodajmy, że nie ma w Stowniku nazwisk... innych poza Przyboś nazwisk od krótkich form nieodmiennych typu przydtuż, przyleń, przyślep, przytyś, przystódz, przywyż. Tłumaczy się to faktem, iż nie uległy one leksykalizacji przed zanikiem. Z kolei wczesna leksykalizacja formacji przyboś, na przyboś stała się podstawą przezwiska i nazwiska.

Bardzo charakterystyczny układ materiału wskazuje na to, że omawiane nazwisko nie występuje w całej Polsce środkowej: w Małopolsce środkowej i północnej, na ziemi sieradzkiej i łęczyckiej, w Wielkopolsce i na Mazowszu (poza Warszawą), na Pomorzu bydgosko-toruńskim (Krajna, Pałuki, Bory Tucholskie, Kociewie, ziemia chełmińsko-dobrzyńska) i rzadko na krańcach zachodnich i północnych. Nie umiem tego inaczej wytłumaczyć jak tylko tym, że na biednym, często fizjograficznie skalistym Podkarpaciu sposób chodzenia boso, przyboś i na przyboś był cechą typową, zauważalną i wyróżniającą, iż dawał podstawę tworzeniu przezwisk, z których powstało nazwisko Przybośs.

Nie możemy współczesnej geografii nazwiska przenieść w przeszłość, ponieważ materiał filologiczny, którym dysponujemy, jest niezwykle skąpy. Stownik staropolskich nazw osobowych poświadcza jednym zapisem z 1400 roku nazwę osobową Przybosz: Prziboszoni, kmethoni de Vituna [Taszycki, red. 1974-1976: 381], a w materiale źródłowym nazewnictwa osobowego

8 Piękny, literacki i językowy obraz życia podkarpackiej wsi i miasta Jasła na przełomie XIX i XX wieku podał w pamiętniku Z Komborni w świat. Wspomnienia młodości Stanisław Pigoń [1983] - s. 75-124 (Moja wieś), s. 125-163 (Mój dom), s. 164-202 (Lata szkolne). 
w ziemi sanockiej i przemyskiej, opracowanym przez Janusza Riegera, nie znajdujemy poświadczenia tej nazwy osobowej [Rieger 1977: 29-33]. Przytoczenie noty z SSNO w całości pozwala cytowaną nazwę osobową umiejscowić w Wielkopolsce:

1400. Nota. Paulus de Posticzino et Jacussius de Weprzki fideiusserunt manu coniuncti Prziboszoni k. de Vituna IIIIor mrc. in IIII sep. p.mediu. na sklat sb p. Reg. A. Kons. Pozn. [Lubomirski 1857: 803, zapis z akt konsystorza poznańskiego]

Jak widać, interesującą nas nazwę osobową w SSNO odczytano jednoznacznie jako Przybosz. Jeżeli zatem w zapisie formy celownika Prziboszoni i w wyabstrahowanej z niej postaci mianownika Przybosz (ściśle w XV wieku Przibosz) dwuznak sz odczytamy jako [š] (miękkie), to może być to przesłanką do wydzielenia w niej morfemu przyrostkowego -osz. W takim wypadku nazwa swoją budową włącza się do ciągu słowotwórczego staropolskich nazw osobowych typu Mit-osz : Mit-o-staw, Rad-osz : Rad-o-staw, Stan-osz : Stan-i-sław itp. Ale czy takie imiona, a tym bardziej przezwiska nadawano chłopom i kmieciom? Wśród polskich przezwisk w XV wieku w ziemi sanockiej i przemyskiej z sufiksem -osz znalazło się tylko miano Dlugosz (Dlugosz, Dlwgosch) od dtugi lub Dlugi. Poza tym: Broda, Gląb, Glod, Nogay, Ogrisek, Zkorupa (tj. Skorupa), Pyrog, Kyelbaska, Barscz, Smyothanka, Pyelucha, Pyoro, Mroz, Gawron, Gąnszyor, Goril, Kogoth, Kokothek, Wrobl, Zambr (od stpol. zabr, ząbrz 'żubr'), Zyobro, Suchozab, Rzathky Groch, Poczyask (od pociask 'narzędzie do wygarniania żaru z pieca' [SStp; Linde 1994-1995, t. 4]), Czychra, Przeksta, Przecora, Pyskadlo, Rospad i wiele im podobnych [Rieger 1977: 29-33]. Przypominają one, nawet są z nimi tożsame, nazwy osobowe z Bulli gnieźnieńskiej (XII wiek): Broda, Goły i Golec lub Gołek, Gęba, Gogoła, Krost, Krostawiec, Okrzos, Piskor(z), Smarż, Świrszcz, Żerzucha itd. [Decyk-Zięba 2003: 51-53; zob. też Wośko 2018]. Wskazane przykłady prostoty nazewniczej ludności wiejskiej skłaniają nas do poszukiwania źródła nazwiska Przyboś w tym środowisku społecznym. Najstarszy zapis Przibosz z Wielkopolski odczytujemy jako Przyboś (ściśle Prziboś), bo oznaczenie wygłosowej spółgłoski dwuznakiem $s z$ upoważnia do lekcji zarówno Przybosz, jak i Przyboś. Bardziej realna wydaje się lekcja Przyboś, ponieważ ma oparcie w wyrazie pospolitym, który łatwiej jednoznacznie odczytać w zapisie średniowiecznym niż nazwę własną. Przez cały XV wiek nie tylko w kancelariach urzędowych, ale i w skryptoriach klasztornych, gdzie powstawały literackie zabytki językowe, dwuznakiem $s z$ oznaczano fonemy [s], [̌̌s, [ś], a nawet [z], 
[ž], [ź] $]^{9}$. Oparcie nazwy na wyrazie pospolitym, jak wspomniano, pozwala odczytać ją jednoznacznie ${ }^{10}$. Tak więc podstawą apelatywną nazwiska jest wcześnie zleksykalizowany przysłówek gwarowy przyboś, na przyboś. Miejscem powstania nazwiska mógł być każdy region historyczny, gdzie występują przysłówek przyboś i jego warianty, a więc w zasadzie cały obszar etniczny języka polskiego (jak pokazują materiały z SGP i MAGP). Miejscem powstania znanego dziś nazwiska Przyboś było Podkarpacie, gdzie i obecnie dane statystyczne potwierdzają zasiedzenie jego nosicieli. Brak nazwiska Przyboś w antroponimii łemkowskiej jest znakiem tego, że karpaccy Rusini nie przyswoili sobie polonizmu przyboś, na przybos ${ }^{11}$. Historyczny wielkopolski zapis Przibosz (Prziboszoni) jest najstarszym poświadczeniem nazwy osobowej i późniejszego nazwiska Przyboś (chociaż nie jest ono bezpośrednią kontynuacją średniowiecznej nazwy osobowej). Jest zarazem pierwszym i jedynym filologicznym świadectwem wyrazu przyboś, który z nazwy osobowej w sposób metodologicznie uzasadniony rekonstruujemy ${ }^{12}$.

Pierwsze i starsze poświadczenia wielu wyrazów słowiańskich, czasem jedyne, odnajdujemy w nazwach własnych, osobowych, miejscowych, w hydronimach i innych. Tak np. nazwy osobowe Puchacz i Puha poświadczone mniej więcej w tym samym czasie co wyraz pospolity puchacz, puhacz 'gatunek sowy' (w SStp dwa warianty pisowniane) pozwalają wiązać ich etymologię z pol. puchać 'zionąć, wyziewać' i z ukr. puhu imitującym głos puchacza (do 1936 roku w pisowni normatywnej puhacz) oraz ukr. puhacz od puhaty (błrus. puhać, ros. pugatb) 'straszyć, wydawać odstraszające okrzyki' [Bańkowski 2000: 962; Boryś 2005: 502; Rytter 1992: 77-78]. Innym przykładem może być nazwa osobowa Drumla poświadczona blisko 150 lat wcześniej (1415 w Wielkopolsce, 1465 we Lwowie) niż rzeczownik pospolity drumla - w 1568 roku u Miko-

9 Zob. Decyk-Zięba, Dubisz, red. 2003, np.: Roty przysiag sądowych - s. 122, Kazania gnieźnieńskie - s. 220-221, Żywot św. Błażeja-s. 150-151, Biblia królowej Zofii-s. 178, Legenda o św. Aleksym - s. 256-257, Rozmowa mistrza Polikarpa ze śmiercia-s. 315-317, Satyra na leniwych chłopów - s. 332.

10 Inaczej bywa z nazwami własnymi, dla których trudno odnaleźć podstawę apelatywną, nierzadko odczytywanymi dwuznacznie [zob. np. Bąk 1968: 25-28; Bańkowski 1986: 441-450].

11 Nie ma tego wyrazu w: Rieger 1995; nazwiska Przyboś nie znalazłem też w pracy Wolnicz-Pawłowskiej [1993]. Nazwiska Przybosz i Prybusz w Polsce Pawło Czuczka podaje za NP, t. 2: 312 (zob. hasło Przyb, s. 311-312). Zakarpackie Прибош wyjaśnia „перенесенням сербського чоловічого імені Прибош на укр. г’рунт, де воно стало прізвищем” [Czuczka 2005: 467].

$12 \mathrm{Z}$ wielu prac poświęconych tej problematyce odnotujemy chronologicznie pierwszą: Kucała 1968 [przedruk: Kucała 2000] i późniejszą: Rzepka, Walczak 1994. 
łaja Reja (węg. doromb, rum. drîmbă) [Bańkowski 2000: 303]. Natomiast zapis nazwy osobowej Chuj 1471 w Wielkopolsce i Łupichuj 1471 ,ironiczne przezwisko żołdaka" wyprzedzają poświadczenie leksykograficzne w 1806 roku wyrazu miejskiego chuj 'penis' (prawdopodobnie ruskie, może w XVII wieku) o 300 lat [Sławski 1952-1956: 89; Bulicz-Tornikidis 1979; Bańkowski 2000, t. 1: 161 - proponuje inną etymologię niż Franciszek Sławski]. Nie zaszkodzi przy tej okazji przypomnieć, że ,nazwy własne wywodzą się z wyrazów pospolitych, i to w znacznej części bezpośrednio" [Kucała 1968: 169], więc wyrazy pospolite musiały istnieć przed powstaniem nazw własnych. Filologicznego poświadczenia nazwiska Przyboś trzeba jeszcze poszukiwać w źródłach antroponimii wiejskiej i miejskiej doby średnio- i nowopolskiej, przede wszystkim na Podkarpaciu. W przejrzanych opracowaniach z tego zakresu nie znalazłem poświadczenia ani nazwiska Przyboś, ani nazwiska Przybosz [Mączyński 1970; Borek, Szumska 1976; Kopertowska 1988; Gala, Piotrowicz 2001: 31-45; Rudnicka-Fira 2004]. Nie zawiera go też najnowsze opracowanie Antroponimia Polski od XVI do końca XVIII wieku [Cieślikowa, red. 2013, t. 4].

Kazimierz Rymut intuicyjnie włączył nazwisko Przyboś do gniazda etymologicznego Przyb, Przyb-os, Przyb-osz, Przyb-oś i wywiódł je od podstawy imiennej typu Przybysław, Przybywoj. Nie końcowy morfem -oś jest jednak elementem formującym nazwę własną Przyboś, jak to może być w przypadku innych nazwisk, np. List-oś i List-os, List-osz od List 1310, Ort-oś i Ort-os od Orzet 1383 [NP, t. 2: 23, 185]. W artykule pokazałem, że nic nie stoi na przeszkodzie stwierdzeniu, a nawet daje się dowieść ludowego pochodzenia regionalnego nazwiska Przyboś od gwarowego przysłówka pochodzenia przymiotnikowego przyboś z przybosy. Wczesna leksykalizacja krótkiej formy nieodmiennej przyboś ‘częściowo, nieco boso' stała się podstawą przezwiska i nazwiska. W świetle danych filologicznych zawartych w opracowaniach polskich nazwisk współczesne nazwisko Przyboś nie jest bezpośrednią kontynuacją staropolskiej nazwy osobowej Prziboś. Pospolity przysłówek przyboś został zrekonstruowany ze średniowiecznego zapisu nazwy osobowej Przibosz, czyli Przyboś, z uwzględnieniem tła w postaci krótkich form nieodmiennych przydtuż, przyłyś, przyleń, przysłódz i podobnych, filologicznie poświadczonych od XVI wieku, co jednak nie wyklucza ich istnienia w polszczyźnie mówionej (w gwarach staropolskich) przed XVI wiekiem. 


\section{Wykaz skrótów}

MAGP - Mały atlas gwar polskich (1957-1970), oprac. przez Pracownię Dialektologiczną Zakładu Językoznawstwa PAN w Krakowie pod kierunkiem Kazimierza Nitscha (t. 1-2), Zdzisława Stiebera (t. 3-6) i Mieczysława Karasia (t. 7-12). Mapy i komentarze do map, t. 13. Indeksy i źródła, Zakład Narodowy im. Ossolińskich, Wydawnictwo PAN, Wrocław.

NP - Rymut Kazimierz (1999-2001), Nazwiska Polaków. Stownik historyczno-etymologiczny, t. 1-2, Wydawnictwo Instytutu Języka Polskiego PAN, Kraków.

SGP - Karłowicz Jan (1900-1911), Stownik gwar polskich, t. 1-6, nakładem Akademii Umiejętności, Kraków.

SGP PAN - Słownik gwar polskich (1982-2016), oprac. przez Zakład Dialektologii Polskiej Instytutu Języka Polskiego PAN w Krakowie pod kier. Mieczysława Karasia, Stanisława Urbańczyka, Jerzego Reichana, (od t. 6) Joanny Okoniowej, t. 1-9, Wrocław (jeszcze nieukończony).

SSNO - Taszycki Witold, red. (1965-1983), Stownik staropolskich nazw osobowych, t. 1-6, Wrocław, t. 7, Suplement, oprac. w Zakładzie Onomastyki Polskiej pod kier. Marii Malec, Zakład Narodowy im. Ossolińskich - Wydawnictwo PAN, Kraków. SStp - Urbańczyk Stanisław, red. (1953-2002), Słownik staropolski, t. 1-11, Zakład Narodowy im. Ossolińskich, Wrocław-Kraków.

\section{Bibliografia}

Bańkowski Andrzej (1986), Dyskusyjne interpretacje niektórych staropolskich nazw osobowych z tzw. Bulli gnieźnieńskiej, „Prace Filologiczne”, s. 441-450.

Bańkowski Andrzej (2000), Etymologiczny słownik języka polskiego, t. 1-2, Wydawnictwo Naukowe PWN, Warszawa.

Bąk Stanisław (1968), W sprawie nazwy osobowej Cirnech, „Slavia Occidentalis”, t. 27 , s. $25-28$.

Borek Henryk, Szumska Urszula (1976), Nazwiska mieszkańców Bytomia od końca XVI wieku do roku 1740, Państwowe Wydawnictwo Naukowe, Warszawa.

Boryś Wiesław (2005), Słownik etymologiczny języka polskiego, Wydawnictwo Literackie, Kraków.

Bulicz-Tornikidis Teresa (1979), Uproszczenia i skrócenia morfologiczne staropolskich przezwisk złożonych, „Język Polski”, s. 177-186.

Brückner Aleksander (1927), Słownik etymologiczny języka polskiego, Krakowska Spółka Wydawnicza, Kraków.

Cieślikowa Aleksandra, red. przy współpracy Katarzyny Skowronek (2006-2016), Antroponimia Polski od XVI do końca XVIII wieku. Wybór artykułów hasłowych 
oraz wykazy nazwisk wraz z chronologia i geografia, t. 1-5, Wydawnictwo Lexis, Kraków.

Czuczka Pawło (2005), Prizwyszcza zakarpatśkych ukrajinciw. Istoryko-etymołohicznyj słownyk, Wydawnictwo „Swit”, Lwiw.

Dal Władimir (1880-1882), Tołkowyj słowarb żywogo wielikorusskogo jazyka, t. 1-4, Izdanie Knigoprodawca-Tipografa M.O. Wolfa, S.-Petersburg.

Dal Władimir (1978-1980), Tołkowyj słowarb żywogo wielikorusskogo jazyka, t. 1-4, Izdatelstwo „Russkij jazyk”, Moskwa.

Decyk-Zięba Wanda (2003), Bulla gnieźnieńska, w: Teksty staropolskie. Analizy i interpretacje, red. Wanda Decyk-Zięba, Stanisław Dubisz, Wydawnictwa UW, Warszawa, s. 31-67.

Decyk-Zięba Wanda, Dubisz Stanisław, red. (2003), Teksty staropolskie. Analizy i interpretacje, Wydawnictwa UW, Warszawa.

Doroszewski Witold (1963), Podstawy gramatyki polskiej, Państwowe Wydawnictwo Naukowe, Warszawa.

Duda Henryk, Koper Mariusz (2009), Co znacza nazwy miejscowe? Etymologie i pseudoetymologie w ,gawędach kresowych” Katarzyny Węglickiej, w: Świat ukryty $w$ słowach, czyli o znaczeniu gramatycznym, leksykalnym i etymologicznym, red. Ilona Generowicz, Elżbieta Kaczmarska, Ignacy M. Doliński, Wydział Polonistyki UW, Warszawa, s. 81-90.

Gala Sławomir, Piotrowicz Elżbieta (2001), Nazwiska historyczne piotrkowian, Łódź.

Karłowicz Jan (1900-1911), Słownik gwar polskich, t. 1-6, nakładem Akademii Umiejętności, Kraków.

Karłowicz Jan, Kryński Adam, Niedźwiedzki Władysław, red. (1900-1927), Słownik języka polskiego, t. 1-8, [b.w.], Warszawa.

Koper Mariusz (2008), Szarowola i gęsi, czyli jak nie popularyzować onomastyki, „Język Polski”, s. 301-304.

Kopertowska Danuta (1988), Nazwy osobowe mieszkańców podkieleckich wsi (1565-1694), Zakład Narodowy im. Ossolińskich, Wrocław.

Kreja Bogusław (2001), Stowotwórstwo polskich nazwisk. Struktury sufiksalne, DWN, Kraków.

Kucała Marian (1968), Odbicie słownictwa pospolitego w staropolskich nazwach osobowych. Na podstawie tomu I „Stownika staropolskich nazw osobowych” $i$,, Słownika staropolskiego”, ,Język Polski”, s. 168-186.

Kucała Marian (2000), Odbicie słownictwa pospolitego w staropolskich nazwach osobowych. Na podstawie tomu I ,Słownika staropolskich nazw osobowych” $i$,,Słownika staropolskiego”, w: tenże, Polszczyzna dawna i współczesna. Studia i szkice, Wydawnictwo Instytutu Języka Polskiego PAN, Kraków, s. 256-272.

Kwiatkowski Jerzy (1972), Świat poetycki Juliana Przybosia, PIW, Warszawa. 
Krzyżanowski Julian, red. (1984-1985), Literatura polska. Przewodnik encyklopedyczny, t. 1-2, Wydawnictwo Naukowe PWN, Warszawa.

Linde Samuel Bogumił (1807-1814), Słownik języka polskiego, t. 1-6, Drukarnia Księży Pijarów, Warszawa.

Linde Samuel Bogumił (1854-1860), Słownik języka polskiego, t. 1-6, wyd. 2, Zakład Narodowy im. Ossolińskich, Lwów.

Linde Samuel Bogumił (1994-1995), Słownik języka polskiego, t. 1-6, wyd. 2 (fotooffsetowe), Wydawnictwo „Gutenberg-Print”, Warszawa.

L[ubomirski] T. (1857), Rolnicza ludność w Polsce od XV do XVI wieku, „Biblioteka Warszawska", t. 2, s. 791-840.

Łoś Jan (1922-1927), Gramatyka polska, cz. 1-3, Zakład Narodowy im. Ossolińskich, Lwów.

Maty atlas gwar polskich (1957-1970), oprac. przez Pracownię Dialektologiczną Zakładu Językoznawstwa PAN w Krakowie pod kierunkiem Kazimierza Nitscha (t. 1-2), Zdzisława Stiebera (t. 3-6) i Mieczysława Karasia (t. 7-12). Mapy i komentarze do map, t. 13. Indeksy i źródła, Zakład Narodowy im. Ossolińskich, Wydawnictwo PAN, Wrocław.

Mączyński Jan (1970), Nazwiska łodzian (XV-XIX wiek), Zakład Narodowy im. Ossolińskich, Łódź.

Perzowa Henryka (1969), Stopniowanie przymiotników polskich z przedrostkiem przy-, Zakład Narodowy im. Ossolińskich, Wrocław.

Pigoń Stanisław (1983), Z Komborni w świat. Wspomnienia młodości, Ludowa Spółdzielnia Wydawnicza, Warszawa.

Rieger Janusz (1977), Imiennictwo ludności wiejskiej w ziemi sanockiej i przemyskiej w XV w., Zakład Narodowy im. Ossolińskich - Wydawnictwo PAN, Wrocław.

Rieger Janusz (1995), Stownictwo i nazewnictwo łemkowskie, Wydawnictwo Naukowe Semper, Warszawa.

Rospond Stanisław (1976), Mówią nazwy, WSiP, Warszawa.

Rudnicka-Fira Elżbieta (2004), Antroponimia Krakowa od XVI do XVIII wieku. Proces kształtowania się nazwiska, Wydawnictwo UŚ, Katowice.

Rymut Kazimierz (1999-2001), Nazwiska Polaków. Słownik historyczno-etymologiczny, t. 1-2, Wydawnictwo Instytutu Języka Polskiego PAN, Kraków.

Rymut Kazimierz, wyd. (1992-1994), Stownik nazwisk współcześnie w Polsce używanych, t. 1-10, PAN, IJP, Kraków.

Rytter Grażyna (1992), Wschodniosłowiańskie zapożyczenia leksykalne w polszczyźnie XVII wieku, Wydawnictwo UŁ, Łódź.

Rzepka Wojciech Ryszard, Walczak Bogdan (1994), Jak dopetnić znany nam obecnie zasób leksykalny staropolszczyzny?, w: Studia historycznojęzykowe I, red. Marian Kucała, Zdzisława Krążyńska, IJP PAN, Kraków, s. 7-13. 
Skoczylas-Stawska Honorata (1976), Z frazeologii gwar wieluńskich, „Studia Polonistyczne", t. 3, s. 163-172.

Sławiński Janusz (1965), Koncepcja języka poetyckiego awangardy krakowskiej, Wrocław.

Sławski Franciszek (1952-1982), Słownik etymologiczny języka polskiego, t. 1-5, Towarzystwo Miłośników Języka Polskiego, Kraków (nieukończony).

Stownik gwar polskich (1982-2016), oprac. przez Zakład Dialektologii Polskiej Instytutu Języka Polskiego PAN w Krakowie pod kier. Mieczysława Karasia, Stanisława Urbańczyka, Jerzego Reichana, (od t. 6) Joanny Okoniowej, t. 1-9, Wrocław (jeszcze nieukończony).

Taszycki Witold, red. (1965-1983), Słownik staropolskich nazw osobowych, t. 1-6, Wrocław, t. 7, Suplement, oprac. w Zakładzie Onomastyki Polskiej pod kier. Marii Malec, Zakład Narodowy im. Ossolińskich - Wydawnictwo PAN, Kraków.

Twardzik Wacław, red. (2005), Opis źródet Stownika staropolskiego, Wydawnictwo Lexis, Kraków.

Urbańczyk Stanisław, red. (1953-2002), Słownik staropolski, t. 1-11, Zakład Narodowy im. Ossolińskich, Wrocław.

Walczak Bogdan (2013), Jak niespecjaliści pisza o językoznawstwie diachronicznym, „Roczniki Humanistyczne”, z. 6: Językoznawstwo, s. 57-75.

Wolnicz-Pawłowska Ewa (1993), Antroponimia łemkowska na tle polskim i słowackim (XVI-XIX wiek), Slawistyczny Ośrodek Wydawniczy, Warszawa.

Wośko Zuzanna (2018), Nazwisko Gogółka w świetle geografii językowej, „Poradnik Językowy", nr 9, s. 96-102.

Zamącińska Danuta (1970), Przyboś wobec Mickiewicza, „Roczniki Humanistyczne”, z. 1, s. 161-174.

Zamącińska Danuta (1971), „Znalezione piórko”, „Roczniki Humanistyczne”, z. 1: O sztuce literackiej. Prace ofiarowane Czesławowi Zgorzelskiemu, s. 203-218.

Zembaty-Michalakowa Maria (1982), Poezja Juliana Przybosia w świetle badań statystyczno-językowych na tle porównawczym, Wydawnictwo UWr, Wrocław.

\section{Zygmunt Gałecki}

\section{The Polish Cant Adverb przyboś, na przyboś and the Surname Przyboś}

The author proves that the etymology of the surname Przyboś came from the lexicalised adverb przyboś, na przyboś (walk), "to wear shoes on bare feet, with a bare foot, (walk) slightly barefoot", that came from the adjective przybosy. The surname did not stem from either compound names such as Przybysław, Przybywój or from the verb 
przybyć, contrary to what has been stated in the historical and etymological dictionary Nazwiska Polaków by Kazimierz Rymut.

KEYWORDS: etymology; history and geography of the adverb przyboś, na przybos'; etymology of the surname Przyboś.

dr hab. prof. nadzw. Zygmunt Gałecki - filolog, językoznawca, polonista i slawista, wykładowca uniwersytetów w Warszawie, Lublinie i Tarnopolu, autor prac naukowych z gramatyki, leksykologii, historii języka polskiego i dydaktyki uniwersyteckiej. 
